\title{
Hubungan tingkat pengetahuan tentang gizi, peer group dan uang saku dengan pemilihan jajanan pada siswa SLTP
}

\author{
Laras Agitya Ratnaningtyas ${ }^{a, 1}$, Intan Wahyuni Tukiyo ${ }^{b, 2, *}$, Helfi Agustinna'3 \\ aprodi Kesehatan Masyarakat, Universitas Ahmad Dahlan, Yogyakarta, Indonesia \\ bProgram Magister IImu Kedokteran Tropis, Universitas Gajah Mada, Yogyakarta, Indonesia \\ 1intanwahyunitukiyo@gmail.com \\ *Correspondent Author
}

ARTICLE INFO

ABSTRACT

Article histor

Received : 15-09-2021

Revised : 23-09-2021

Accepted : 03-10-2021

Keywords

Ecological behavioualr model,

Food security,

Snacking behavior
Poor nutritional behaviour among students is the increasing of snacking proportion and the consumption unnutritious and unsafe food. The aims of the study was to know the determinants of school children's snack behavior using behavioural ecological model. This was a cross-sectional study design based on ecological models behaviour. The study was conducted at a state junior high school in Sleman Regency, D.I Yogyakarta. The sample was 80 students of 381 students. The data were analyzed by the chi-square test. The result showed that only 52.5\% students had selected behaviour in snacking, 50\% students had a good level of knowledge about nutrition and food security, 68.8\% had a large amount of pocket money, 83.8\% had breakfast habit, 70\% were highly influenced by peers. There were significant relations between knowledge about nutrition and food security and breakfast habits. There were no significant relations between the amount of pocket money, peers with students' behaviour to the selection of snacks in the State Junior High School in Sleman, Special Region Yogyakarta. It is recommended for schools to strengthen their school health institutions through increasing the role of student cadres and counseling about nutrition and food safety in the provision of healthy canteens. Include content about nutrition and the consequences of consuming unsafe food, placing posters on healthy and unhealthy food in the school canteen. Schools are also advised to provide socialization to parents and students about the importance of having breakfast and bringing lunch from home.

This is an open-access article under the CC-BY-SA license.

\section{Pendahuluan}

Sarapan bermanfaat untuk meningkatkan konsentrasi dan kemampuan belajar anak di sekolah. Siswa yang terbiasa sarapan akan lebih kooperatif, bersemangat dan akan lebih mudah fokus pada saat belajar. Siswa yang tidak sarapan pagi cenderung menambah asupan energi dan zat gizi dengan jajan di sekolah untuk menyediakan energi bagi tubuh dan agar anak tetap mudah menerima pelajaran (1). 
Dalam dekade terakhir, jajan sangat lazim bagi banyak anak dan remaja di dunia, namun makanan yang dikonsumsi seringkali makanan yang tidak bergizi. Di USA dan Australia $95 \%$ anak terbiasa jajan, sedangkan di Mexico terdapat $76 \%$ dan di China $65 \%$ anak memiliki kebiasaan jajan atau memakan camilan tidak bergizi (2). Di Indonesia, menurut laporan akhir hasil monitoring dan verifikasi profil keamanan Pangan Jajan Anak Sekolah (PJAS) Nasional tahun 2014, masih banyak jajanan anak sekolah tidak aman dikonsumsi. Dari 10.429 sampel pangan yang diuji dari seluruh Indonesia, sebanyak $23,82 \%$ tidak memenuhi syarat. Penyebabnya adalah cemaran mikroba $(74,9 \%)$, penggunaan bahan tambahan pangan $(15,7 \%)$ dan penggunaan bahan berbahaya (9\%) (3). Hasil temuan BPOM pada Januari- Agustus 2014, hampir 1/3 dari 23.500 sekolah dasar dan Madrasah Ibtidaiyah mengandung cemaran mikrobiologi, bahan kimia berbahaya, penggunaan bahan tambahan makanan yang melebihi batas aman (4).

Cara pengolahan tidak tepat dan makanan tidak aman di pasaran, kantin-kantin sekolah, dan penjaja makanan di sekitar sekolah merupakan agen penting yang bisa membuat siswa mengkonsumsi makanan tidak sehat. Pada penelitian tentang pola konsumsi makanan ringan dan junkfood pada anak-anak dan remaja di Iran didapatkan hasil bahwa pola konsumsi makanan di Iran dalam kategori yang buruk baik dalam kebiasaan mengknsumsi makanan maupun frekuensi mengkonsumsi makanan cepat saji (5), sedangkan di Indonesia, hasil pengujian terhadap 10.429 sampel PJAS yang berasal dari survei di seluruh Indonesia pada anak SD/MI menunjukkan 76,18\% sampel makanan memenuhi syarat dan $23,82 \%$ sampel tidak memenuhi syarat. Menurut Kemenkes RI (2014 sampel makanan yang tidak memenuhi syarat ini disebabkan karena menggunakan bahan berbahaya yang dilarang untuk pangan, penggunaan bahan makanan tambahan yang melebihi batas maksimal, kualitas mutu mikrobiologis pangan yang tidak memenuhi syarat serta bahan pangan yang tercemar logam berat melewati batas maksimal (6).

Pemilihan jajanan merupakan perwujudan perilaku. Perilaku ini meliputi pengetahuan, persepsi, sikap dan praktik terhadap makanan serta zat gizi yang terkandung dalam makanan, pengolahan makanan, dan lainnya yang berhubungan dengan kebutuhan tubuh. Pemilihan jajanan yang buruk dapat mempengaruhi gangguan kesehatan dan memiliki efek jangka panjang(7). Untuk mengatur perilaku gizi di masyarakat, Undang-undang No. 18 Tahun 2012 tentang Pangan menyatakan bahwa penyelenggaraan pangan bertujuan untuk meningkatkan pengetahuan dan kesadaran masyarakat tentang pangan yang aman, bermutu, dan bergizi bagi konsumsi masyarakat.

Menurut teori ekologi perilaku, individu merupakan bagian dari sistem sosial. Perkembangan individu dipengaruhi oleh sistem lingkungannya. Interaksi antara individu dan lingkungan terjadi dalam proses yang dinamis dan multidimensi. Sistem lingkungan itu mencakup keluarga, peer group, sekolah (mikro system) dan lingkungan masyarakat, termasuk kebijakan intrapersonal, antarpribadi, organisasi, komunitas dan publik (meso system), yang dapat memengaruhi perilaku kesehatan individu $(8,9)$.

Penelitian Sogari (2018) menemukan bahwa faktor ekologi perilaku pemilihan jajanan sehat pada anak sekolah. Terdiri dari faktor internal dan eksternal. Faktor internal adalah pengetahuan yang biasanya dipengaruhi oleh tingkat pendidikan, sedangkan faktor eksternal adalah perilaku makan orang tua, kebiasaan sarapan dalam keluarga dan tekanan sosial dari teman sebaya yang dapat berpengaruh positif atau negatif pada kebiasaan makan individu (10).

Hasil pemantauan PHBS Pendidikan Tingkat SLTP Tahun 2016-2017 di Kabupaten Sleman, indikator capaian mengkonsumsi makanan dan minuman sehat mencapai 90,7\%. Sebagian besar SMP belum memprioritaskan pengelolaan kantin sehat di sekolah, bahkan kerap kali menjajakan makanan dan minuman kemasan (11). Hal serupa juga penelitian temukan pada hasil survey pendahuluan di sebuah SMP negeri di Sleman Yogyakarta. Sekolah tersebut belum memiliki fasilitas kantin sehat karena jarak sekolah dan pasar berdekatan sehingga intervensi dan pembinaan mengenai pengawasan PJAS tidak mudah dilakukan oleh sekolah. Perilaku jajan yang mengkonsumsi jajanan yang tidak sehat dan tidak aman tentu akan berpengaruh terhadap kesehatan dan prestasi siswa di sekolah. Berdasarkan hal tersebut maka peneliti ingin 
mengetahui faktor apa saja selain dari faktor keberadaan kantin yang dapat mempengaruhi perilaku jajan anak sekolah dengan menggunakan teori model ekologi perilaku.

\section{Metode}

Jenis penelitian ini adalah penelitian kuantitatif dengan desain cross sectional study. Penelitian dilakukan di sebuah Sekolah Menengah Pertama Negeri (SMPN) di Kabupaten Sleman, Daerah Istimewa Yogyakarta pada tahun 2019. Variabel dependen yaitu perilaku jajan anak sekolah ditandai dengan tingkat pengetahuan siswa tentang gizi dan keamanan pangan (individu), sedangkan variabel independen terdiri dari, peran keluarga (mikro system) terlihat dari ketersediaan sarapan di rumah dan pemberian uang saku oleh orang tua dan peran masyarakat dilihat dari pengaruh teman sebaya (meso system). Populasi pada penelitian ini berjumlah 381 siswa. Penentuan besar sampel menggunakan rumus Slovin dengan presisi mutlak 10\%. Sampel didapat 80 siswa. Sampel ditetapkan secara proporsional dari setiap kelas. Berdasarkan jumlah proporsi maka jumlah sampel dari siswa kelas VII sebanyak 27 orang, siswa kelas VIII sebanyak 27 orang dan siswa kelas IX sebanyak 26 orang. Setelah itu sampel dipilih secara cluster random berdasarkan kelas. Kelas VII yang terdiri atas 4 kelas paralel dipilih secara random 1 kelas sehingga terpilih kelas VII C, kelas VIII yang terdiri atas 4 kelas paralel terpilih kelas VIII D, dan kelas IX yang terdiri atas 4 kelas paralel terpilih kelas IX D. Kriteria Inklusi sampel adalah bersedia menjadi responden dan memiliki kebiasaan jajan di sekolah. Data dikumpulkan dengan kuesioner dan dianalisis dengan uji statistik chi-square.

Pertanyaan kuesioner berjumlah 58 butir soal. Kuesioner pada variabel peran teman sebaya dan perilaku/ praktik memilih jajanan menggunakan skala Likert yang pada jawaban pertanyaan menggunakan jawaban selalu, sering, kadang-kadang dan tidak pernah. Pertanyaan tentang perilaku/praktik memilih jajanan terdapat dua tipe yaitu favourable dan unfavourable. Pertanyaan favourable pada variabel praktik memilih jajanan dengan jawaban "selalu" nilainya 4, "sering" nilainya 3, "kadang-kadang" nilainya 2 dan "tidak pernah" nilainya 1 dan sebaliknya untuk pertanyaan unfavourable. Pertanyaan perilaku pemilihan jajanan yang bergizi nilainya 1 , jika responden sarapan istirahat 1 memilih camilan, tidak sarapan istirahat 133 memilih makanan utama, dan istirahat 2 memilih makanan utama; nilainya 0 , jika responden sarapa istirahat 1 memilih makanan utama, tidak sarapan istirahat 1 memilih camilan.

Pengetahuan gizi dan keamanan pangan yaitu kemampuan responden menjawab benar pertanyaan kuesioner mengenai makanan bergizi dan keamanan pangan. Masing-masing variabel dikategorikan berdasarkan hasil skoring. Kategori tingkat pengetahuan rendah jika skor $=<$ median (Med=17) . Variabel uang saku yaitu jumlah uang yang diperoleh responden dari orang tua setiap hari dalam bentuk rupiah, dikategorikan besar apabila jumlah uang saku $\geq$ median (Med=10.000), kebiasaan sarapan yaitu kegiatan makan dan minum responden yang dilakukan antara bangun pagi di rumah sampai sebelum berangkat sekolah, dikategorikan tidak biasa, apabila tidak pernah atau jarang dilakukan setiap pagi, peran teman sebaya yaitu hubungan responden dengan temannya yang memberi pengaruh terhadap kebiasaan memilih makanan jajanan, dikategorikan rendah apabila skor < median (Med=13). Perilaku memilih jajanan yaitu tindakan yang dilakukan responden dalam menentukan atau memilih jajanan sehat yang didasari atas kecukupan gizi makanan serta keamanan pangan, dikategorikan menjadi perilaku kurang baik jika skor $<$ median $($ Med $=41$ ).

Uji validitas menggunakan rumus Korelasi Pearson Product Moment, dari total item pertanyaan yang berjumlah 76 butir, terdapat 18 item soal pertanyaan yang tidak valid. Dikatakan valid jika rhitung > rtabel, sebaliknya jika rhitung < rtabel 34 maka butir soal tersebut tidak valid. Selain itu juga membaca hasil uji berdasarkan nilai signifikansi (p) yang besarnya 0,000 yang dibandingkan dengan nilai $a=5 \%$, dimana nilai $\mathrm{p}<0,05$ sehingga menunjukkan bahwa butir soal tersebut valid karena memiliki hubungan yang signifikan antara butir soal dengan skor total soal. Uji reliabilitas menggunakan Model Alpha Cronbach. Butir soal dikatakan reliable minimal 0,7. 
Hasil uji reliabilitas dari 58 butir soal yang valid diketahui bahwa keseluruhan butir soal tersebut memiliki nilai cronbach's alpha lebih dari 0,7 sehingga butir soal yang valid dan reliabel sebanyak 58 butir soal. Butir soal yang tidak valid dan reliable tersebut dihapus dan tidak digunakan dalam penelitian.

Analisis bivariat dilakukan untuk menguji masing-masing hubungan antar variabel bebas yaitu pengetahuan gizi dan keamanan pangan, uang saku, peran teman sebaya, kebiasaan sarapan dengan variable terikat yaitu perilaku memilih jajanan. Tingkat kepercayaan yang digunakan sebesar $95 \%$ dan nilai p value $\leq 0,05$. Uji statistik yang digunakan adalah uji Chi square $2 \times 2$.

\section{Hasil dan Pembahasan}

Dari Tabel 1 dapat dilihat bahwa hampir separuh siswa (47,5\%) memiliki perilaku kurang baik dalam pemilihan jajanan. Perilaku jajan yang baik biasanya didasari oleh tingkat pengetahuan seseorang (12). Sesuai dengan teori tersebut dari temuan penelitian ini, peneliti menemukan tingkat pengetahuan yang rendah tentang gizi dan keamanan pangan dimiliki oleh $50 \%$ responden. Peran keluarga dalam pengambilan keputusan untuk jajan terlihat dari jumlah uang saku, responden yang memiliki uang saku besar $68,8 \%$, dan responden yang terpengaruh oleh teman sebaya saat memilih jenis makanan jajanan sebanyak 70\%. Dari jawaban responden, sebagian besar responden terbiasa sarapan di rumah (83,8\%). Tabel 1 menampilkan kategori dari masing-masing variabel penelitian.

Tabel 1. Distribusi Frekuensi Variabel Penelitian

\begin{tabular}{lcc}
\hline \multicolumn{1}{c}{ Variabel } & n & Presentase (\%) \\
\hline \multicolumn{2}{l}{ Pengetahuan Gizi dan Keamanan Pangan } & \\
\hline Rendah & 40 & 50 \\
\hline Tinggi & 40 & 50 \\
\hline Uang Saku & & \\
\hline Besar & 55 & 68,8 \\
\hline Kecil & 25 & 31,2 \\
\hline Kebiasaan Sarapan & & \\
\hline$\quad$ Tidak biasa & 13 & 16,3 \\
\hline Biasa & 67 & 83,8 \\
\hline Peran Teman Sebaya & & \\
$\quad$ Rendah & 24 & 30 \\
\hline$\quad$ Tinggi & 56 & \\
\hline Perilaku Pemilihan Jajanan & & \\
\hline$\quad$ Kurang baik & 38 & 57,5 \\
\hline$\quad$ Baik & 42 & 100 \\
\hline Total & 80 & \\
\hline
\end{tabular}

Pengetahuan merupakan faktor yang sangat penting untuk terbentuknya tindakan seseorang. Pengetahuan yang didasari dengan pemahaman yang tepat akan menumbuhkan perilaku yang diharapkan(13-15). Ketidaktahuan dapat menyebabkan kesalahan dalam mengambil keputusan memilih jajanan dan mengkonsumsi bahan makanan. Responden mendapatkan pengetahuan tentang fungsi makanan, unsur-unsur gizi dari mata pelajaran di sekolah, akan tetapi materi mengenai akibat dari mengkonsumsi bahan pangan yang tidak aman, tidak higienis dan tidak memiliki cukup nilai gizi tidak terlalu ditekankan. Sekolah sebaiknya juga memberikan pengetahuan mengenai pangan yang aman yang juga melibatkan kondisi tempat dan penjual yang sehat dan bersih, pilihan makanan dan kebiasaan membaca label dengan seksama. 
Hasil uji statistik hubungan tingkat pengetahuan gizi dan keamanan pangan dengan perilaku individu dalam pemilihan jajanan, ditemukan responden yang memiliki perilaku pemilihan jajan kurang baik lebih banyak berasal dari responden yang pengetahuannya rendah (65\%). Hasil uji statistik diperoleh nilai $p$ value sebesar $0,014(\mathrm{p}<0,05)$. Dapat disimpulkan ada hubungan yang signifikan antara pengetahuan gizi dan keamanan pangan dengan perilaku pemilihan jajanan pada siswa di salah satu SMP Negeri di Kabupaten Sleman Yogyakarta.

Kurangnya pengetahuan tentang gizi dan pangan yang aman menyebabkan siswa tidak mempunyai kemampuan untuk menerapkan informasi dalam memilih makanan jajanan yang merupakan sumber zat gizi, sehat dan aman dikonsumsi (cenderung memilih makanan jajanan yang murah, enak, dan menarik), sehingga kebiasaan dalam konsumsi makanan jajanan yang kurang baik, akan mempengaruhi asupan gizi dan pertumbuhan dan perkembangan tubuh. Pangan yang aman merupakan pangan yang bebas dari cemaran biologis, kimia dan benda lain yang dapat mengganggu, merugikan dan membahayakan kesehatan manusia. Keputusan siswa untuk berperilaku jajan dan cara memilih pangan aman yang dapat dilihat dari kemasan pangan yang tidak rusak, terlihat bersih, tidak basi, tekstur tidak menyimpang dari keadaan normal, tidak terlalu kenyal, keras tidak berasa pahit/getir tidakberwarna mencolok, tidak dibungkus dengan kertas koran/kertas bekas dan tidak menggunakan bahan tambahan pangan yang berlebihan. Selain itu pangan juga bebas dari benda asing seperti rambut, serpihan kayu, kerikil serta tidak dibungkus dengan pembungkus yang distapler.

Penelitian ini sejalan dengan penelitian Hatta yang menyatakan bahwa ada hubungan antara pengetahuan dengan pemilihan makanan jajanan pada siswa di sekolah dasar Inpres Maccini Sombala Kota Makassar(13). Hal ini menandakan bahwa pengetahuan gizi dan keamanan pangan merupakan faktor yang mendukung responden dalam hal pemilihan jajanan. Pengetahuan mengenai jajanan adalah kepandaian memilih jajanan yang merupakan sumber zat-zat gizi dan kepandaian dalam memilih jajanan yang aman dari bahan tambahan makanan berbahaya. Pengetahuan tentang keamanan dan kebersihan makanan ditemukan memiliki hubungan yang signifikan secara statistik dengan praktek keamanan dan kebersihan makanan(16).

Sebagai bagian dari system sosial (mikro, meso, makro), pengetahuan tidak hanya diperoleh dari orang tua, keluarga, sekolah namun juga dari media massa, tenaga kesehatan, dll. Selain orang tua pengetahuan gizi dan jajanan anak yang paling mudah diperoleh dari sekolah. Sebaiknya pengetahuan anak tentang gizi dan jajanan lebih diperkuat dan disesuaikan dengan hal-hal yang sering ditemuinya seperti pemasangan poster di kantin sekolah, penguatan kelembagaan UKS melalui peningkatan peran pengkaderan siswa dan penyuluhan dari puskesmas sehingga pengetahuan tentang gizi dan keamanan pangan lebih mudah diaplikasikan dalam perilakunya sehari-hari. Hubungan tingkat pengetahuan gizi dan keamanan pangan dengan perilaku individu dalam pemilihan jajanan, dapat dilihat pada Tabel 2:

Tabel 2. Variabel Individu; Hubungan Tingkat Pengetahuan tentang Gizi dan Keamanan Pangan dengan Perilaku Pemilihan Jajan

\begin{tabular}{|c|c|c|c|c|c|c|}
\hline \multirow{3}{*}{$\begin{array}{c}\text { Pengetahuan } \\
\text { Gizi }\end{array}$} & \multicolumn{6}{|c|}{ Perilaku Jajanan } \\
\hline & \multicolumn{2}{|c|}{ Kurang baik } & \multicolumn{2}{|c|}{ Baik } & \multicolumn{2}{|c|}{ Total } \\
\hline & $\mathrm{N}$ & $\%$ & $\mathrm{~N}$ & $\%$ & $\mathrm{~N}$ & $\%$ \\
\hline Rendah & 26 & 65 & 14 & 35 & 40 & 100 \\
\hline Tinggi & 14 & 35 & 26 & 65 & 40 & 100 \\
\hline Total & 40 & 50 & 40 & 50 & 80 & 100 \\
\hline
\end{tabular}

Hasil uji statistik tentang hubungan antara jumlah uang saku dengan perilaku pemilihan jajanan terlihat pada responden yang perilaku pemilihan jajanannya kurang baik, lebih banyak berasal dari responden dengan uang saku besar (54,5\%). Hasil uji statistik diperoleh nilai $p$ value sebesar 0,335 $(\mathrm{p}>0,05)$. Dapat disimpulkan bahwa tidak ada hubungan yang bermakna 
(signifikan) antara jumlah uang saku dengan perilaku pemilihan jajanan pada pada siswa di SMP Negeri X di Kabupaten Sleman Yogyakarta.

Temuan ini tidak sejalan dengan penelitian yang dilakukan oleh Rahayu (2018), yang menunjukkan terdapat hubungan yang bermakna antara jumlah uang saku dengan pemilihan makanan jajanan anak. Uang saku yang rutin diberikan pada anak dapat membentuk sikap dan persepsi anak bahwa uang saku adalah hak mereka dan mereka bisa menuntutnya. Kurangnya nasihat dan arahan dari orang tua tentang pemanfaatan uang saku mendorong anak untuk memanfaatkannya secara bebas(17).

Dari hasil penelitian terlihat bahwa perbedaan jumlah uang jajan yang diterima tidak membuat anak terampil dalam menentukan jajanan sehat. Uang jajan yang besar dan tidak didukung dengan pengetahuan gizi dan makanan jajanan yang baik, dapat menyebabkan kebiasaan konsumsi makanan jajanannya lebih sering. Hal itu karena pada siswa yang tidak memiliki pengetahuan gizi dan keamanan jajanan yang 'baik', menyebabkan mereka sulit menerapkan informasi terkait gizi dan makanan jajanan, sehingga mereka cenderung memilih makanan jajanan yang murah dan enak, tanpa memperhatikan nilai-nilai gizinya.

Hasil uji statistik tentang hubungan antara jumlah uang saku dengan perilaku pemilihan jajanan dapat dilihat pada Tabel 3.

Tabel 3.Variabel Keluarga; Hubungan Pemberian Uang Saku dan Sarapan dengan Perilaku Jajan

\begin{tabular}{lcccccc}
\hline \multirow{2}{*}{ Perilaku Jajan } & \multicolumn{2}{c}{ Kurang baik } & \multicolumn{2}{c}{ Baik } & \multicolumn{2}{c}{ Total } \\
\cline { 2 - 7 } & $\mathrm{n}$ & $\%$ & $\mathrm{n}$ & $\%$ & $\mathrm{n}$ & $\%$ \\
\hline Uang saku & & & & & & \\
\hline Besar & 30 & 54,5 & 25 & 45,5 & 55 & 100 \\
\hline Kecil & 10 & 40 & 15 & 60 & 25 & 100 \\
\hline Total & 40 & 50 & 40 & 50 & 80 & 100 \\
\hline $\begin{array}{l}\text { Kebiasaan } \\
\text { Sarapan }\end{array}$ & & & & & & \\
\hline Tidak biasa & 11 & 84,6 & 2 & 15,4 & 13 & 100 \\
\hline Biasa & 29 & 43,3 & 38 & 56,7 & 67 & 100 \\
\hline Total & 40 & 50 & 40 & 50 & 80 & 100 \\
\hline \multicolumn{7}{l}{ PValue uang saku=0,334, PValue sarapan $=0,015$} \\
\end{tabular}

Hubungan antara kebiasaan sarapan dengan perilaku pemilihan jajanan juga dapat dilihat pada tabel 3 . Responden yang perilaku pemilihan jajanannya kurang baik lebih banyak berasal dari responden yang tidak biasa sarapan $(84,6 \%)$. Hasil uji statistik diperoleh nilai $p$ value sebesar 0,015 $(\mathrm{p}<0,05)$ dapat disimpulkan bahwa ada hubungan yang bermakna antara kebiasaan sarapan dengan perilaku pemilihan jajanan pada siswa di SMP Negeri X di Kabupaten Sleman Yogyakarta.

Penelitian ini sejalan dengan penelitian yang dilakukan oleh Rahayu yang menunjukkan ada hubungan yang bermakna antara kebiasaan sarapan dengan pemilihan makanan jajanan siswa sekolah dasar negeri Gentan(18). Penelitian ini juga sejalan dengan penelitian Alamin yang menunjukkan bahwa ada hubungan yang signifikan antara sarapan pagi di rumah dengan pemilihan makanan jajanan di sekolah(19). Dengan sarapan maka dapat memenuhi kebutuhan energi pada saat beraktifitas sehingga tidak mudah lapar. Sedangkan anak bila tidak sarapan akan meningkatkan peluang anak untuk lebih sering jajan.

Sarapan mempunyai peranan penting dalam pemenuhan kebutuhan energi anak sekolah(20). Sarapan pagi pada umumnya menyumbang gizi sekitar $25 \%$ dari angka kebutuhan gizi sehari, sarapan sebagai makanan yang paling penting untuk peningkatan memori(21). Anak yang tidak sarapan pagi cenderung mengonsumsi energi dan zat gizi lebih sedikit daripada anak yang sarapan pagi. Sebanyak 17,3 \% responden tidak mempunyai kebiasaan sarapan. Sering kali orang 
mengabaikan sarapan karena diburu oleh waktu yang sempit. Sebagian orang harus meninggalkan rumah sejak pagi-pagi untuk beraktivitas di tempat kerjanya. Sementara di rumah sarapan pagi belum tersedia, akhirnya sarapan ditinggalkan tanpa adanya perasaan bersalah. Sebesar $46,1 \%$ responden yang tidak sarapan beralasan takut terlambat jika harus sarapan terlebih dahulu, 80,6\% sarapan dengan gizi yang kurang lengkap, karena hanya mengkonsumsi roti, mie, nasi dan lauk tanpa sayur, nasi dan sayur tanpa lauk atau buah. Oleh sebab itu kebiasaan sarapan ini perlu diperhatikan secara khusus terutama oleh orang tua. Menyediakan menu sarapan yang bergizi namun menggungah selera dapat menarik minat anak.

Berdasarkan hasil penelitian hanya 37,5\% responden yang membawa bekal. Pemberian bekal terhadap anak harusnya diiringi dengan pemberian menu yang mengandung gizi seimbang yang sesuai dengan kebutuhan anak. Pemberian bekal pada anak dapat menghindarkan anak dari kebiasaan jajan yang sekaligus menghindarkan anak dari gangguan penyakit akibat makanan tidak bersih. Pengawasan terhadap asupan gizi, kebersihan dan keamanan makanan dapat dilakukan melalui pemberian bekal. Jika rasa lapar dan kebutuhan energinya dapat terpenuhi melalui bekal yang dibawa maka kecenderungan membelanjakan uang sakunya untuk jajanan menjadi menurun. Kepala sekolah harus memiliki komitmen yang tinggi untuk melaksanakan manajemen pemenuhan gizi seimbang anak sekolah. Hal ini dapat dilakukan dengan memberikan sosialisasi kepada orang tua/ wali murid tentang pentingnya sarapan dengan gizi lengkap dan bekal yang baik sehingga asupan gizi, kebersihan dan keamanan makanan siswa dapat terpenuhi.

Hubungan antara peran teman sebaya dengan perilaku pemilihan jajanan juga dapat dilihat pada Tabel 4.

Tabel 4. Variabel Masyarakat; Hubungan Peran Teman Sebaya dengan Perilaku Jajan

\begin{tabular}{lcccccc}
\multirow{2}{*}{ Peran Teman Sebaya } & \multicolumn{6}{c}{ Perilaku Jajanan } \\
\cline { 2 - 8 } & \multicolumn{2}{c}{ Kurang baik } & \multicolumn{2}{c}{ Baik } & \multicolumn{2}{c}{ Total } \\
\cline { 2 - 8 } & $\mathrm{n}$ & $\%$ & $\mathrm{n}$ & $\%$ & $\mathrm{n}$ & $\%$ \\
\hline Rendah & 16 & 66,7 & 8 & 33,3 & 24 & 100 \\
\hline Tinggi & 24 & 42,8 & 32 & 57,2 & 56 & 100 \\
\hline Total & 40 & 50 & 40 & 50 & 80 & 100 \\
\hline & & \multicolumn{4}{c}{ PValue $=0,088$}
\end{tabular}

Dari temuan penelitian, responden yang perilaku pemilihan jajanannya kurang baik tidak terlalu terpengaruh oleh peran teman sebaya (42,8\%). Hasil uji statistik diperoleh nilai $p$ value sebesar $0,088(p>0,05)$.

Temuan penelitian ini tidak ada hubungan yang signifikan secara statistik antara peran teman sebaya dengan perilaku memilih jajanan pada siswa SMP Negeri di Sleman, akan tetapi jika diperhatikan persentasi siswa dengan perilaku jajan kurang baik, banyak terjadi pada siswa yang tidak terlalu dipengaruhi oleh teman sebaya, sebaliknya perilaku jajan yang baik lebih banyak dilakukan karena adanya pengaruh/peran yang besar dari teman sebaya. Walaupun sebagian responden 'sering' (32,5\%) dan 'selalu' (50\%) membeli jajanan bersama teman bermain namun dalam hal memilihnya berdasarkan keinginan pribadi. Kemungkinan ini terjadi karena responden tidak memiliki tekanan untuk menyesuaikan tingkah lakunya termasuk dalam memilih jajanan agar tidak ditolak dalam pergaulan, dan responden bebas menentukan pilihan jajanan yang disukai.

Teman sebaya dapat memberikan pengaruh yang kuat pada diri seorang anak dan pada situasi tertentu pengaruh teman sebaya ini lebih besar dari keluarga. Lingkungan sekolah memiliki dampak signifikan pada pemilihan makanan(22) Anak secara tiba-tiba dapat meminta makanan baru atau menolak makanan yang biasanya sering dikonsumsi karena usulan teman. Perilaku makan orang tua dan tekanan dari teman sebaya dianggap memiliki pengaruh positif dan negatif pada kebiasaan makan individu(10). 
Penelitian Arisdanni menunjukkan ada hubungan antara peran teman dengan kenaikan IMT/U, semakin tinggi peran teman, maka akan semakin tinggi pula IMT/U. hal ini menunjukkan bahwa peran teman berhubungan dengan pola makan anak yang dapat meningkatkan atau menurunkan status gizinya. Saat berada di sekolah atau di luar rumah anak sering mengkonsumsi makanan bersama temannya, dimana salah satu pengaruh kuat teman adalah dalam pemilihan makanan yang tidak sehat(23). Secara teori ekologi, individu dan orang tua anak sekolah dalam hal penyediaan sarapan masih mempunyai peran yang kuat dalam menentukan perilaku jajan. Lingkungan sekolah sebagai lingkungan meso bagi siswa mempunyai peranan penting untuk menyediakan pangan jajanan yang aman, bermutu dan bergizi melalui keberadaan kantin dan pedagang di luar sekolah.

Upaya yang dapat dilakukan untuk meningkatkan kualitas sumber daya manusia pada kelompok anak sekolah adalah menyediakan makanan jajanan yang bergizi dan aman dengan harga yang terjangkau di kantin sekolah. Kepala Sekolah sebaiknya melakukan penguatan kelembagaan kantin sekolah dengan membentuk Tim Keamanan Pangan (TKP) Sekolah. Hal ini untuk memastikan penyediaan PJAS kantin sekolah serta TKP dapat memonitor kemajuannya. Pelaksanaan kegiatan edukasi dalam pemenuhan gizi seimbang juga dapat dilakukan oleh guru dan TKP pada siswa sekolah bersama dengan komite sekolah, orang tua, siswa, pengelola kantin dan/atau penjaja makanan yang difasilitasi oleh ahli gizi dan sanitarian dari puskesmas setempat (4).

\section{Kesimpulan}

Dari hasil penelitian di SMP Negeri X Kabupaten Sleman ditemukan ada hubungan yang signifikan antara pengetahuan gizi dan keamanan pangan serta kebiasaan sarapan di rumah dengan perilaku pemilihan jajanan. Disarankan sekolah untuk melakukan penguatan kelembagaan UKS melalui peningkatan peran pengkaderan siswa dan penyuluhan dari puskesmas sehingga pengetahuan tentang gizi dan keamanan pangan lebih mudah diaplikasikan dalam perilakunya sehari-hari. Pembelajaran di kelas selain membahas tentang gizi juga perlu menekankan pada akibat jika tidak mengkonsumsi makanan yang aman. Pengetahuan anak tentang gizi dan jajanan perlu diperkuat dengan pemasangan poster di kantin sekolah. Selain sekolah, pengetahuan gizi dan jajanan anak yang paling mudah diperoleh dari orang tua. Oleh sebab itu sekolah juga disarankan untuk memberikan sosialisasi pada orang tua siswa dan siswa tentang pentingnya sarapan dan membawa bekal dari rumah.

\section{Konflik Kepentingan}

Tidak Ada konflik kepentingan

\section{REFERENSI}

1. Rakhman AFT. Hubungan Kebiasaan Melewatkan Sarapan dan Pemilihan Jajanan dengan Kejadian Wasting di Desa Sembung, Kecamatan Wringinanom , Kabupaten Gresik Association between Skipping Breakfast and Selection of Snack Food with Wasting Incident in Sembung Village , Wr. E-journal Univ Airlangga. 2018;237-44.

2. Wang D, Van Der Horst K, Jacquier EF, Afeiche MC, Eldridge AL. Snacking patterns in children: A comparison between Australia, China, Mexico, and the US. Nutrients [Internet]. 2018;10(2):1-14. Available from: www.mdpi.com/journal/nutrients

3. Infodatin: Bawa Bekal Nasional [Internet]. 2020. Available from: https://pusdatin.kemkes.go.id/article/view/20111200001/hari-bawa-bekalnasional.html

4. Manalu HSP, Suudi A. Kajian Implementasi Pembinaan Pangan Jajanan Anak Sekolah (PJAS) untuk Meningkatkan Keamanan Pangan: Peran Dinas Pendidikan dan Dinas Kesehatan 
Kota. Media Penelit dan Pengemb Kesehat [Internet]. 2017;26(4):249-56. Available from: http://ejournal.litbang.depkes.go.id/index.php/MPK/article/view/5734/4650

5. Mirkarimi K, Mansourian M, Kabir MJ, Ozouni- RB. Fast food consumption behaviors in high-school students based on the theory of planned behavior (TPB). Intrenational J Pediatr. 2016;4(7):2131-42.

6. Kementerian Kesehatan RI. Situasi pangan jajanan anak sekolah. In 2014.

7. Mithra P, Unnikrishnan B, Thapar R, Kumar N, Hegde S, Mangaldas Kamat A, et al. Snacking Behaviour and Its Determinants among College-Going Students in Coastal South India. J Nutr Metab. 2018;1-6.

8. Sunarti E, Islamia I, Rochimah N, Ulfa M. Pengaruh faktor ekologi terhadap resiliensi remaja. 2017;10(2):107-19.

9. Glanz K, Rimer BK, Viswanath K. Health Behavior and Health Education [Internet]. 4th ed. Glanz K, Rimer BK, K. Viswanath, editors. Jossey Bass A Willey Brand; 2008. 4 p. Available from:

http://140.112.36.179:8080/uploads/bulletin_file/file/568a39ae9ff546da4e02eb72/Hea lth_behavior_and_health_education.pdf\#page $=227$

10. Sogari G, Velez-Argumedo C, Gómez MI, Mora C. College Students and Eating Habits: A Study Using An Ecological Model for Healthy Behavior. Nutrients [Internet]. 2018;10(12):1-16. Available from: http://www.ncbi.nlm.nih.gov/pubmed/30477101\%0Ahttp://www.pubmedcentral.nih.g ov/articlerender.fcgi?artid=PMC6315356

11. Dinas Kesehatan Kabupaten Sleman. Profil Kesehatan Kabupaten Sleman. 2018. 1-80 p.

12. Notoatmojo S. Promosi Kesehatan Teori dan Aplikasi. Jakarta: Rhineka Cipta; 2012.

13. Hatta H, J. Hadi A, Yetti R E, Tombeg Z, Manggabarani S. Hubungan Faktor Pemilihan Makanan Jajanan Siswa di Sekolah Dasar Inpres Maccini Sombala Kota Makassar. J Kesehat. 2018;1(4):355-63.

14. Handayani S, Hartono. Hubungan Pengetahuan Guru Dan Pengelola Kantin Tentang Gizi Btp (Bahan Tambahan Pangan) Terhadap Penggunaan Btp Beresiko Pada Makanan Anak Sd Di Surakarta. J Terpadu Ilmu Kesehat. 2016;5(2):110-237.

15. Permatasari P, Sharadea. Strategi Promosi Kesehatan Terhadap Upaya Peningkatan Pengetahuan Pengelola Kantin Sehat. J Media Publ Promosi Kesehat Indones. 2018;1(3):69-74.

16. Afolaranmi T, Hassan Z, Bello D, Misari Z. Knowledge and practice of food safety and hygiene among food vendors in primary schools in Jos, Plateau State, North Central Nigeria. E3 J Med Res. 2015;4(2):16-22.

17. Widajanti L, Suryawati C, Sugihantono A. Pengaruh Komik Makanan Jajanan Sehat dan Bergizi untuk Meningkatkan Pengetahuan dan Sikap Anak Sekolah Dasar. Indones J Public Heal. 2009;6(1):19-23.

18. Rahayu S. Related Factors With Selection of Students Food in Gentan Elementary. J Pendidik Tek Boga. 2018;6(7):1-9.

19. Alamin RL, Syamsianah A, Mufnaetty. Hubungan Sarapan Pagi di Rumah dan Jumlah Uang Saku Dengan Konsumsi Makanan Jajanan di Sekolah Pada Siswa SD N Sukorejo 02 Semarang. J Gizi Univ Muhammadiyah Semarang. 2014;3(1):40-50.

20. Desi, Suaebah, Astuti WD. Hubungan Sarapan, uang saku dengan Jajanan di SD Kristen Immanuel II Kubu Raya. J Vokasi Kesehat. 2018;(7):48-53.

21. Batis C, Rodríguez-Ramírez S, Ariza AC, Rivera JA. Intakes of Energy and Discretionary Food in Mexico Are Associated with the Context of Eating: Mealtime, Activity, and Place. J Nutr. 2016;146(9):1907S-1915S.

22. Neumark-Sztainer D, French SA, Hannan PJ, Story M, Fulkerson JA. School lunch and snacking patterns among high school students: Associations with school food environment and policies. Int J Behav Nutr Phys Act. 2005;2(14):1-7. 
Jurnal Cakrawala Promkes

Vol 3, No. 2,Agustus 2021, pp. 77-86

23. Arisdanni, Buanasita AN. Hubungan Peran Teman, Peran Orang Tua , Besaran Uang Saku dan Persepsi Terhadap Jajanan Dengan Kejadian Gizi Lebih Pada Anak Sekolah. Amerta Nutr. 2018;189-96. 